\title{
The Mediating Role of Absorptive Capacity in Its Effect on Organizational Support Factors and Technological Innovation
}

\author{
*Abdul Qadir Rahomee Ahmed Aljanabi, Nor Azila Mohd Noor, Dileep Kumar M \\ Othman Yeop Abdullah Graduate School of Business (OYA-GSB), University Utara Malaysia \\ *janabi76@gmail.com
}

\begin{abstract}
The purpose of this research is to examine the relations between organizational support factors and absorptive capacity and their combined effects on technological innovation. Through a comprehensive literature review constructs were developed. Multiple regression analysis used to test research hypotheses based on a sample of 52 engineers within the Directorate of Electricity in Sulaimani city in Kurdistan region north of Iraq. Based on empirical research, the results showed that organizational support factors had a significant effect on technological innovation and absorptive capacity. It was also indicated that absorptive capacity plays a full mediation rule between organizational support factors and technological innovation. This appears to be the first research to test the relationships between organizational support factors and absorptive capacity and their consequences in the particular context of technological innovation including product innovation and process innovation.
\end{abstract}

Keywords: Organizational Support Factors (OSF), Absorptive Capacity (AC), Technological Innovation (TI), Knowledge

\section{Introduction}

The business environment has become increasingly sophisticated and restricted. Therefore, it is complicated for an organization to create internally all the required knowledge to obtain the required innovation. The organization must, consequently, be able to acquire and exploit knowledge existing in relationships with their allies. Many factors that influence an institution's ability to absorb knowledge generation. Just for example, the characteristics of transferred knowledge; the ease of transfer and the shorter time to determine and transfer, the ability of formulate and use it in achieving innovation etc., especially in some certain and vital areas, such as the production of electric power which represents one of the basic needs of the people nowadays in the world in general and in Iraq in particular, where Iraq has suffered from shortages in the provision of electric power for more than 20 years. Due to the importance of the topic, there is a need for a deeper explores into the nature of such organizational factors, organization's absorptive capacity, and to test their relationship to organizational competitive advantage in achieving innovation in serving the interests of citizens.

Given the fast changes in business environment nowadays, organizations capability to achieve TI readily through external knowledge has become an essential determinant for success (Wang \& Han, 2011). Despite the ability of organizations to generate knowledge internally (Martinkenaite, 2012) there is a growing need to relying on external knowledge (Laukkanen, 2012) due to the limitations of capitals for some organizations in hand (Tseng et al., 2011) and overly depending on internal knowledge can lead to organizational myopia on the other hand (Zahra \& Hayton, 2008). However, reviewing the related literature observed that empirical studies concerning the interaction between OSFs and ACAP seem to be surprisingly rare, despite the enormous increasing importance of ACAP of external generated knowledge and the factors that may affect it in achieving TI; most studies drew their attention towards the relationship between ACAP and organizational learning (Andersén, 2012; Dixon \& Day, 2007) while others focused on the mechanism aspects for developing ACAP (Sparrow et al., 2009; Jung-Erceg et al., 2007) and the role of prior knowledge in fortify absorption process of new knowledge (Minguela-Rata et al., 2012; Deng, 2010; Caccia-Bava et al., 2006). As regards to the factors that may affect ACAP, most of scholars focused their attentions on the individual impact of specific management characteristics, managerial practices (Dixon \& Day, 2007) and some organizational factors (Andersén, 2012). Thus, the insufficient researches that have established the relationships that may exist 
between the variables of current research create the theoretical gap within the context of our research. This research rely on one of the issues leading to the existing gap in ACAP research is the lack of general consensus about the factors that may affect the ACAP and how the components of ACAP are to be determined and measured as a mechanism to foster TI. In addition, to that the majority of these studies have been conducted within mature and stable economies and developed countries. Therefore it is important to extend this study on the effect of OSF and ACAP on TI within the context of developing economy like Kurdistan region of Iraq.

Rationale View of this Research: As regards to the practical side, Special Inspector General for Iraq Reconstruction (SIGIR) in (2012) reported that there is a noticeable lack of coverage citizens' needs of electric power, even with the Ministry of Electricity in Baghdad imports about $16 \%$ of its electricity from Iran and about $100 \mathrm{MW}$ from Syria into Anbar county in addition to Iraqi local grids (Bowen, 2012), till now there is a substantial lack of electricity. On the other hand, the ministry of electricity in Kurdistan Region Government (KRG) reported that it expected residents in the Kurdistan Region in the north of Iraq to rec eive 20 hours of electricity each day from its grid only during June and July 2012. Moreover, with the availability of financial resources allocated to the electricity sector which amounted to $(3,638.0)$ \$Millions just in 2010 budget and owning the required infrastructure like the largest power plant in the Middle East - with the 2,540 MW in Wassit county which established in collaboration with Shanghai Electric (SIGIR, 2012), in addition to continuous training courses outside Iraq dedicated to gain new knowledge (Zair, 2012) and the owning of Kurdistan Region to huge stations in its counties there is an inability to provide electrical power permanently, furthermore, the poor treatment of maintenance problems, especially when rainfall or during hot summer times which is attributed to the lack of required practical knowledge and inefficient OSFs which enhance the development of ACAP and take advantage of external expertise.

Based on the above-mentioned practical issues (weakness of providing electric power even with the abundance of needed physical and financial resources to provide enough energy for citizens) and existing theoretical gaps, this research has investigated the relationships between OSFs dimensions; namely (Management support for idea generation; Allocation of free time; Work discretion; Performance based reward System ;Tolerance for risk taking) and TI, the relationships between OSFs and ACAP in addition to the combined effects of OSFs and ACAP as a mechanisms to achieve TI within the Directorate of Electricity in Sulaimani city in Kurdistan region northern of Iraq. This research is structured as follows: first, it summarized the relevant literature on organizational support factors, absorptive capacity and technological innovation; second, it suggests a model that captures relationships among the examined variables followed by empirical approach and the results of research. Finally, the results are discussed and research suggestions are proposed.

\section{Literature Review}

This section tries to submit an overview of related literature to our research variables namely organizational support factors (OSFs); Absorptive capacity (ACAP) in its two dimensions potential absorptive capacity and realized absorptive capacity and the third variable Technological innovation (TI). In addition, this section sheds light on the mediating role of absorptive capacity.

Organizational Support Factors: According to previous studies in ACAP field, many internal factors can facilitate ACAP. Such internal antecedents creating foundations for ACAP include an existing knowledge base and an organizational culture and structures that allow absorptive capacity to flourish (Laukkanen, 2012; Zahra \& George, 2002). Few studies have discussed the capacity to absorb external knowledge from an organizational approach (Andersén, 2012) to foster TI. However, OSFs in Alpkan et al. (2010) study has adopted in this research for its suitability to investigate the direct and interactive effects of organizational support on the TI of companies. In addition, these items have been developed and tested by previous study of Kuratko et al. (1990), thus they are valid to evaluate OSFs.

Management support for idea generation: Management support, refers to the degree at which management establishes a facilitative environment to support, trust, and cooperation to accomplish goals (Akguna et al., 2007). According to Tarafdara and Vaidyab (2006) top management can help in creating a positive inclination to adopt new ideas and innovations by providing infrastructure for adoption of new 
technologies and clearly defining the role and the importance of these technologies. On the other hand management support for problem solving and conflict solution represent an essential component in the idea generation stage, development, and a particular implementation of this new idea (Alpkan et al., 2010). In addition to its indispensable role in ensuring appropriate learning activities result in facilitating the process of absorbing new knowledge (Saidi et al., 2012). That because management support for idea generation acts as constraints or parameter for organizational actions that, in turn, affects TI.

Allocation of free time: The abundance of free time for employees is another important factor for their both daily activities and innovation of new ideas and encourages them to take risks for putting their new ideas into practice (Alpkan et al., 2010). Although time has considered as an important factor that determine innovation process, few studies have tried to clarify the relationship between time allocation and innovation (Darini et al., 2011). According to Indreicaa et al. (2011) time considered an essential resource in learning and acquisition of new knowledge. In this regard Akguna et al. (2007) reported that employees may feel threatened if there is a lack of time to accomplish their tasks. Therefore managers seeking to motivate employees to exploit their time efficiently to facilitate productivity and alleviate work stress (Darini et al., 2011). Without doubt, a product of human thought is embodied in human's innovation and that production process requires the provision of appropriate and necessary production factors, and here, time is one of the most important factors that must be available to the human thought to introduce its new products "innovation".

Work discretion: Work discretion refers to the convenience of the organizational structure, regarding to decision-making level and the freedom of take actions on one's own career in the lower level of management (Summers et al., 2010). It also represents initiatives taken by employees to improve their work or to resolve problems (Alpkan et al., 2010). Work discretion determined by three of factors: the internal task environment, the organizational structure and the executive employees themselves (Jing et al., 2010). Innovation process affected heavily by degree of work autonomy, within this sense, Gurkov (2005) indicates that the hardness of organizational structures may hinder innovation process and the implementation of new ideas. This means that work discretion allows individuals to do something quite different that has noteworthy influence on the technological innovation ultimately.

Performance based reward system: Reward represents all valuable things in the point of view of individuals and the employer is willing to offer as compensation for the employee's achievement (Chianga \& Birtchb, 2008). Different types of rewards can play a significant role in supporting the skills and abilities of employees and organization (Güngör, 2011) and enhancing new product performance, new knowledge acquisition and innovation (Chianga \& Birtchb, 2008; Wei \& Gima, 2009; Moreno \& Meléndez, 2011) especially when determined in light of its outcome and goals (Bhardwaj \& Sushil, 2012). Alpkan et al. (2010) concluded that if the employees have trust in their organization reward system they will work to ensure the success of their organization, in this sense both of them will be adhered to the innovation process. Thus, organizational reward systems may be varied to recognize individuals or group accomplishments. Furthermore, various types of incentives can be harnessed to boost the welfare of work life in support of innovation within the organization.

Tolerance for risk taking: Recent study for Faff et al. (2011) revealed that many factors can affect employee's risk taking such as age, gender, level of education, marital status and income. However, risk avoided behavior of the managers may reduce the confidence of workers and reduces the level of innovation (Alpkan et al., 2010) since employees need a morale motivations and supportive environment to enhances their risk-taking tendencies (Akguna et al., 2007) on the other hand different organizations have different tendencies towards innovators adoption and their ability to risk taking, by this strategy some organization can overcome the rules of the game by strategically redefining their needs and focusing on some areas often ignored by their competitors (Jin \& Navare, 2011). In the light of previous studies it can be said that different aspects of organizational support factors are critical drivers of technological innovation and its can be used to facilitate and enhance organizations' absorptive capacity for fostering innovation process. Thus, managers should not solely focus on TI resources but, more importantly, on organizational factors that are directly and indirectly affected TI to create business value. 
Absorptive Capacity: The focus on external knowledge transfer received considerable interest among researchers since about 50 years ago (Sparrow et al., 2009) after the seminal contributors of Cohen and Levinthal in the early of 1990s the concept of "absorptive capacity" (Flatten et al., 2011) has emerged and has been used successfully in several studies that have investigated knowledge transfer between organizations (Andersén \& Kask, 2012). A wide stream of literature (Andersén, 2012; Martinkenaite, 2012; Andersén \& Kask, 2012; Tseng et al., 2011) argued that ACAP defined as "the capability of recognizing, assimilating, and applying external knowledge". While Zahra and George (2002) provided another turn to the definition, they are separating the ACAP structure into two main dimensions: potential absorptive capacity (the capability to acquire and assimilate knowledge) and realized absorptive capacity (the transformation and exploitation of knowledge). In addition, they suggested that the switching from assimilation step to transformation step regard as a transformation from potential absorptive capacity to realize absorptive capacity. This measure from the other side has been criticized since it still problematic and treats ACAP as static resources not process or capability (Andersén \& Kask, 2012). However, Zahra \& George (2002) contribution have tested by many studies and proved its suitability to explain the mechanism of ACAP and this search agreed with the dimensions provided by Zahra and George study. ACAP has been debated by some scholars from different standpoints of views; according to Sparrow et al. (2009) ACAP is a dynamic capability consists of four different organizational capabilities: acquisition, assimilation, transformation and exploitation. Obviously they have focused on knowledge exchange interrelationships between organizations. Whereas Caccia-Bava et al. (2006) shed the light on the results or consequence of ACAP when defined it as the organization's ability to estimate the importance of new knowledge, assimilate it, and apply it to a productive outcome. However, these criticisms did not provide any new additional dimensions to ACAP essence developed by Zahra and George, rather they deal with the consequences of this concept. Hence, based on aforementioned discussions and in the footsteps of Zahra \& George (2002), the authors define ACAP as a set of organizational capabilities and qualifications, by which organizations acquire, assimilate, transform, and exploit external knowledge from partners to produce a dynamic capacity for innovation. Hence, in light of the debates above; ACAP includes four essential components:

Acquisition: Acquisition capability refers to an organization's capability to recognize diagnosis and obtain specific knowledge that is externally generated and significantly to its activities (Jung-Erceg et al., 2007). Acquisition has significant opportunities to the regeneration of organizations. First, by acquisition capability organizations can get rapid entry to particular knowledge and skills that may have already been developed in the other organizations. Second, acquisition furnishes the advantage of obtaining the ownership and direct hold of new knowledge and capabilities that are owned by the target firms (Martinkenaite, 2012). Industry, in particular, is witnessing great openness to share knowledge assets even at small organization's level, and thus contribute to knowledge acquisitions (Laukkanen, 2012) as a result of rapid changes in the manufacturing technologies which stimulates organizations to participate in knowledge acquisitions (Amiryany et al., 2012). According to Miczka and Gröbler, (2010) acquisitions of new knowledge can add value to an organization's competitive advantage because the innovation of focal organization is improved through the transferred strategic capabilities, and that does not enhance the organizational performance only; but also elevate as more internal research and development (R\&D) efforts to generate new knowledge (Liu, 2010).

Assimilation: Assimilation capability denotes to an organization's capability to process, analyze, explain and comprehend the information, knowledge and skills acquired from external sources (Kamal \& Flanagan, 2012). Assimilation process as the vivid evolution of knowledge (Yolles et al., 2011) considered the essential component in the organizational learning and an integral factor for competitive advantage (Fletcher \& Prashantham, 2011) that because organizations do not configure relationships with other parties just to acquire valuable and strategic resources, but also to enhance inter-organizational learning (Jung-Erceg et al., 2007). Organization's assimilated knowledge is not limited to single individual but depends upon interactions and knowledge sharing among individuals (Caccia-Bava et al., 2006) thus individuals transfer knowledge, not organizations, even though individuals need to access to specific resources within their organizations (Sparrow et al., 2009) and such communication among individuals and groups encourage knowledge assimilation that allows organizations to manage new knowledge externally generated (Fletcher \& Prashantham, 2011). In this regard, Laukkanen (2012) highlighted that developing ACAP oftentimes requires a participation in a value network to exchange knowledge among persons and refine their ideas. 
Transformation: Transformation capability basically refers to an organization's capability to integrate the newly acquired knowledge with the existing knowledge through a bundle of procedures that facilitate utilization of integrated knowledge (Flatten et al., 2011). Martins (2012) argued that Knowledge transfer is a process that implies integrated dual ties between the source and recipient organizations. Organizations try to gain both tacit and explicit forms of knowledge (Fletcher \& Prashantham, 2011) because of these forms are indispensable to create new knowledge and they complemented each other (Kamasak \& Bulutlar, 2010). On the other hand, the basis of transforming knowledge from tacit form to explicit form and vice versa is manifested by the interaction among individuals and groups; and that can embodied in the release of individual's tacit knowledge into the shared documents and reflection on that explicit textual knowledge (Feghali \& El-Den, 2008). However, knowledge transfer is not at all an assured outcome (Martinkenaite, 2012) that because ideas and knowledge that take place behind the organization's search area are condones because the organization cannot easily grasp those (Han \& Erming, 2012).

On the other hand, the relationship between the organizations affected by the amount of benefit that collaboration may generate (Andersén \& Kask, 2012). Thus, in order to receive knowledge an organization has to share knowledge (Kamasak \& Bulutlar, 2010) and the issue here is not about undeveloped organizations or those operating with limited activities. Within this context, Andersén (2012) adds the concept of protective capacity (PC) which can be understood as a firm's capacity to sustain, or to reduce the velocity of the diminishing of rare knowledge assets by imitating from others. Organizations may rely on several methods to transfer new knowledge, such as group problem solving and thinking along as a mechanism to transfer new knowledge (Sparrow et al., 2009) the transfer process of new knowledge can be considered efficient when the transmitted knowledge can be retained and result in raise the level of innovation (Moreno \& Meléndez, 2011; Martins, 2012). Sparrow et al. (2009) argued that transferred knowledge between parties may not be efficient enough because differences between groups in terms of the culture, educational backgrounds and different fields of expertise. The second reason is that ambiguous natural tacit knowledge which requires close cooperation with the external knowledge source.

Exploitation of knowledge: Exploitation capability essentially indicates an organization's capability to implement the transformed knowledge into its production and operations to maintain continuous growth (Kamal \& Flanagan, 2012). Liu and Hsu (2011) assumed that the exploitation of present knowledge resources and capabilities can result into sustainable competitive advantage. However, some organization may have the capacity to transfer knowledge but a less skillful to exploit knowledge externally generated (Andersén, 2012) due to many obstacles, involving, organization's resistance to change, deficiency of effective knowledge sharing techniques and the difference between the new external knowledge and the organization's prior knowledge (Bierly et al., 2009). Moreover, the mere existence of external knowledge does not adequate to achieve successful absorption (Wang \&Han, 2011). In this regard, Laukkanen (2012) stated that innovation does not depend on knowledge alone but on how to apply it. Therefore the way of acquired, retained, transferred and applied knowledge lift the attention of researchers from analyzing knowledge as a source to analyzing organization's capabilities that generate internally new knowledge and merge it with other resources for creating innovation; either formally through coordination, formalization with partners, or informally through socialization process (Martinkenaite, 2012) based on the dual role of absorptive capacity to generate knowledge internally and to enable organizations to identification, absorption and assimilation knowledge from external sources (Michailova \& Jormanainen, 2011). ACAP in this context represents the organization's capability to search for necessary external knowledge and then recombined it with previous knowledge in order to meet market requirements and such capability necessitates certain conditions to be met:

- The capability to diagnose urgent external knowledge;

- The capability to take advantage of this knowledge and combined it with prior knowledge; and

- The capability to activate this knowledge and directed it towards future innovation.

In other word, ACAP represent the capability of organization to skimming the external knowledge and the effectiveness of its communication processes.

Technological Innovation: There is no a general consensus about what exactly innovation means and how many types of it exists (Murat \& Baki, 2011). Thus, this research focuses on the most common employed type of Technological Innovation like (Chung, 2012; Ren et al., 2010; Arpaci, 2010) depending on the area that will 
be affected by innovation within the organization. However, technological innovation can be understood through two dimensions; product and process, while product innovation refers to forming a new intangible product grade or applying small size changes to existing physical products for the benefit of customers (Ooi et al., 2012). Process innovation is defined as methods, work arrangement, production means, and knowledge in throughput technology that mediate between inputs and outputs (Murat \& Baki, 2011). Generally, innovations stem from a flash of genius and represent the deliberated efforts to achieve a specific goal (Drucker, 2002). Academic literatures, however, refer to two main sources of technological innovation External Source and Internal Source; depending on the source of knowledge that generate innovation. As regards the firs, customers needs and business partners represent the most important source as indicated by IBM study. Consultants, Suppliers, Competitors, Associations, Academia, Labs and other institutions (Laukkanen, 2012; Ramadani \& Gerguri, 2011) represent an important external source of innovation especially for small and medium organizations due to the limited labs and financial resources in such organizations, so they can create alliances with universities or research centers and get up-to-date information (Laforet, 2011). While, Drucker (2002) argued that demographic changes, changes in perception, attitudes and the creation of new knowledge represent an important opportunity for innovation.

On the other hand, internal source represents the second spring for TI, where internal R\&D efforts, employees, internal sales and service units (Ramadani \& Gerguri, 2011) and learn from the long experience and from failure sometimes are major sources for TI (Andersén \& Kask, 2012; Dixon \& Day, 2007) in the meantime unexpected occurrence, incongruities and process needs represent an important sources of innovation (Drucker, 2002). In this sense, TI is about the ability to integrate and activate both of internal and external knowledge to create products or process not known or experienced before in their current form and have the ability to commercial usage to achieve the benefits for both innovative organization and its customers. In other words, new knowledge whether externally or internally generated represents the specific TI need to raise practical experience of employees to solve different problems that may face them.

Mediating Role of Absorptive Capacity: In addition to the OSFs that have been mentioned earlier in this research, many organizational factors can influence ACAP. According to Flatten et al. (2011) existing knowledge, the size and age of organization can play a significant role in developing ACAP, Laukkanen (2012) reported that characteristics of generated ideas, the abundance time of transfer and the convenience of best transfer method available represent a major dominant factors to transfer knowledge. Within this framework, Nagati and Rebolledo (2012) argue in their study, that R\&D facilities submitted in the organization could provide it with great opportunity to improve its innovative skills and facilitate the absorption of new external knowledge, by coping with the scuttle of knowledge and environmental turbulence (Jung-Erceg, et al., 2007). In addition, R\&D efforts allow organizations to transfer huge bodies of tacit knowledge to explicit knowledge over serious difficulties to achieve innovation (Wang \& Han, 2011) since R\&D serves as a proxy for ACAP (Zahra \& Hayton, 2008). However, knowledge as a strategic resource is largely scattered between deferent organizations (Jung-Erceg et al., 2007) and the generation and renovation of knowledge is not limited to the organization borders (Nagati \& Rebolledo, 2012) but previous stock of knowledge as organizational resource can play a fundamental role to absorb new knowledge (Deng, 2010) and that explains why some organizations can acquire and assimilate external knowledge, but not able to transform and exploit it in effectively way to achieve innovation (Caccia-Bava et al., 2006). Finally, Lin et al. (2012) concluded that real need to transferred knowledge is the major determination to be absorbed successfully. Overall, while different researchers focused on different factors, ACAP seems to be based on the organizational similarity between the transmitter and receiver in deferent terms and the more similarities means more of successful transfer as well as it depends on the characteristics of taken knowledge. The above section of this paper earlier indicates the dimensions of OSFs which may influence on TI and ACAP, coming section of this paper build up our hypothesis test, data analysis and discussion of results.

Research Questions: This research explores the role of OSFs in the improvement of TI through the relationships developed with ACAP. Thus, this research attempts to answer the following questions:

- What is the relationship between Organizational Support Factors and Technological Innovation?

- What is the relationship between Organizational Support Factors and Absorptive Capacity?

- What is the relationship between Absorptive Capacity and Technological Innovation? 
- Does the Absorptive Capacity positively mediate the relationship between Organizational Support Factors and Technological Innovation?

Research Objectives: This research is designed to evaluate the effect of OSFs on TI and examine the mediating effect of ACAP on TI within the Directorate of Electricity in Sulaimani city in Kurdistan region north of Iraq. To simplify this, the research has designed the following objectives to grasp the research problem and provide answers to the research questions.

- To determine the relationship between Organizational Support Factors and Technological Innovation.

- To determine the relationship between Organizational Support Factors and Absorptive Capacity

- To determine the relationships between Absorptive Capacity in its two dimensions and Technological Innovation

- To determine whether Absorptive Capacity positively mediate the relationship between Organizational Support Factors and Technological Innovation

Hypothesis: To illustrate and test the relationships between OSFs and TI, ACAP is used. The proposed model in Figure1 suggests that OSFs affects an organization's ACAP and this relation in turn may impact the TI. OSFs represent an important component to facilitate the innovation process in the organization (Laukkanen, 2012; Zahra and George, 2002). Within this context, Howell and Boies (2004) noted that leaders may engage in coalition with other organization to obtain organizational support for the innovation if their organizations unable to provide adequate organizational support for innovation to thrive. Organizational factors have an outstanding role especially in supporting idea generation. Wu and Fang (2010) remarked that idea can considered as the starting point of innovation and organizations can obtain this idea from interactions between R\&D staff and marketing employees or even through the relations between buyer and seller depending on the nature of its structure and the degree of freedom or discretion allowed. Moreover, Martínde Castro et al. (2013) highlighted the significant effect of organizational factors on practices and tools relating to innovation. Thus, innovation activities within a firm will help people to stratify their creative thoughts, give a message to employees that they and their ideas are valued and facilitating continual creativity and change (Akgun et al., 2010) and such cooperative behavior leads to a confidence in the significance of new products and process for firm success and that will improve commitment in innovation and motivation people to it. Within this context, this research presents the following hypothesis:

H1. There is an overall positive relationship between Organizational Support Factors and Technological Innovation.

The relationship between OSFs and ACAP has been an important topic in innovation management literature. Liao et al. (2010) proposed that organization with an organic structure and an open communications climate is more likely to obtain new knowledge's productivity and flexibility benefits. Tarafdara and Vaidyab (2006) argued the OSFs with focusing on management support for idea generation dimension has a significant effect on develop and adopt applications with new knowledge and technology. While Laukkanen (2012) highlighted that these OSFs represent an internal antecedent building block for ACAP. Such results have been proved by some studies which have examined the relationship between organizational antecedents and firm ACAP (Jansen et al., 2005; Dasgupta et al., 2011). In light of the literature, this research has formulated the following hypothesis:

H2. There is an overall positive relationship between organizational support factors and absorptive capacity.

On the other hand, ACAP plays a direct role in achieving TI (Gebauer et al., 2012; Laforet, 2011) according to Caccia-Bava et al. (2006) ACAP can help in fostering TI facilely, and it can also determine the extent to which value can be created (Laukkanen, 2012) by identifying the rapidity, frequency, and volume of innovation (Tseng et al., 2011). Within this context, Wang and Han (2011) reported that innovation depends on the organizations ability to turn both internal and external knowledge into action and outcomes and depends not on the knowledge itself. Wu and Fang (2010) noted that Organizations attempt to merge knowledge by providing facilitative conditions for knowledge sharing between individuals and groups and to achieve the highest level of innovation. In a more detailed insight, acquisitions of new knowledge as one of the ACAP dimensions can add value to organization's competitive advantage (Miczka \& Gröbler, 2010). Whereas, Assimilation process as the vivid evolution of knowledge (Yolles et al., 2011) considered the essential component in the organizational learning and an integral factor for competitive advantage (Fletcher \& 
Prashantham, 2011). Moreover, transformation process has essential role in achieving firm's innovation (Hall \& Andriani, 2003). In addition, exploitation of present knowledge can result in to sustainable competitive advantage and promote innovation, that because firm's ability to innovate depends on its ability to exploit the available knowledge (Laukkanen, 2012). Thus the third hypothesis is:

H3. There is an overall positive relationship between absorptive capacity and technological innovation.

Firms seeking to obtain external knowledge from different sources by using different mechanisms in a move to increase the levels of innovation (Jung-Erceg et al., 2007; Weigelt \& Sarkar, 2012). Many of the previous studies have supported the notion that ACAP plays a direct role in achieving innovation (Tsai, 2001; Laforet, 2011; Gebauer et al., 2012; Laukkanen, 2012). Along these lines, different scholars discussed different dimensions of OSFs in different terms includes: Management support for idea generation (Tarafdara \& Vaidyab, 2006), Allocation of free time (Indreicaa et al., 2011), Work discretion (Gurkov, (2005), Performance based reward system (Chianga \& Birtchb, 2008; Wei and Gima, 2009; Moreno \& Meléndez, 2011) and Tolerance for risk taking (Alpkan et al., 2010) and they proved the existence of a prominent role of these OSFs in the activation process of ACAP to benefit from extremely generated knowledge.

Although new knowledge offer organization new strategic alternatives, a challenge may exist in effectively managing both the knowledge itself and the people who will use it, in a manner that promotes innovation process within the organization (Liao et al., 2010). According to Caccia-Bava et al., (2006) ACAP can help in fostering technological innovation (TI) facilely, and it can also determine the extent to which value can be created (Laukkanen, 2012), by identifying the rapidity, frequency, and volume of innovation (Tseng et al., 2011). Within this context, researchers, e.g., (Liao et al., 2010; Wang \& Han, 2011) reported that innovation depends on the organizational ability to turn both internal and external knowledge into action and outcomes and depends not on the knowledge itself. Thus it can be concluded that the ACAP role represents a systematic relationship, where organizational factors, resources and R\&D play the role of inputs the ACAP playing the role of processing to obtain final outputs in the form of innovation. Thus, fourth hypothesis is:

$H 4$. Absorptive capacity positively mediates organizational support factors and technological innovation.

By combining the above debates into one framework, the following illustration (Figure 1) can be drafted; this depicts the influence relations between examining variables.

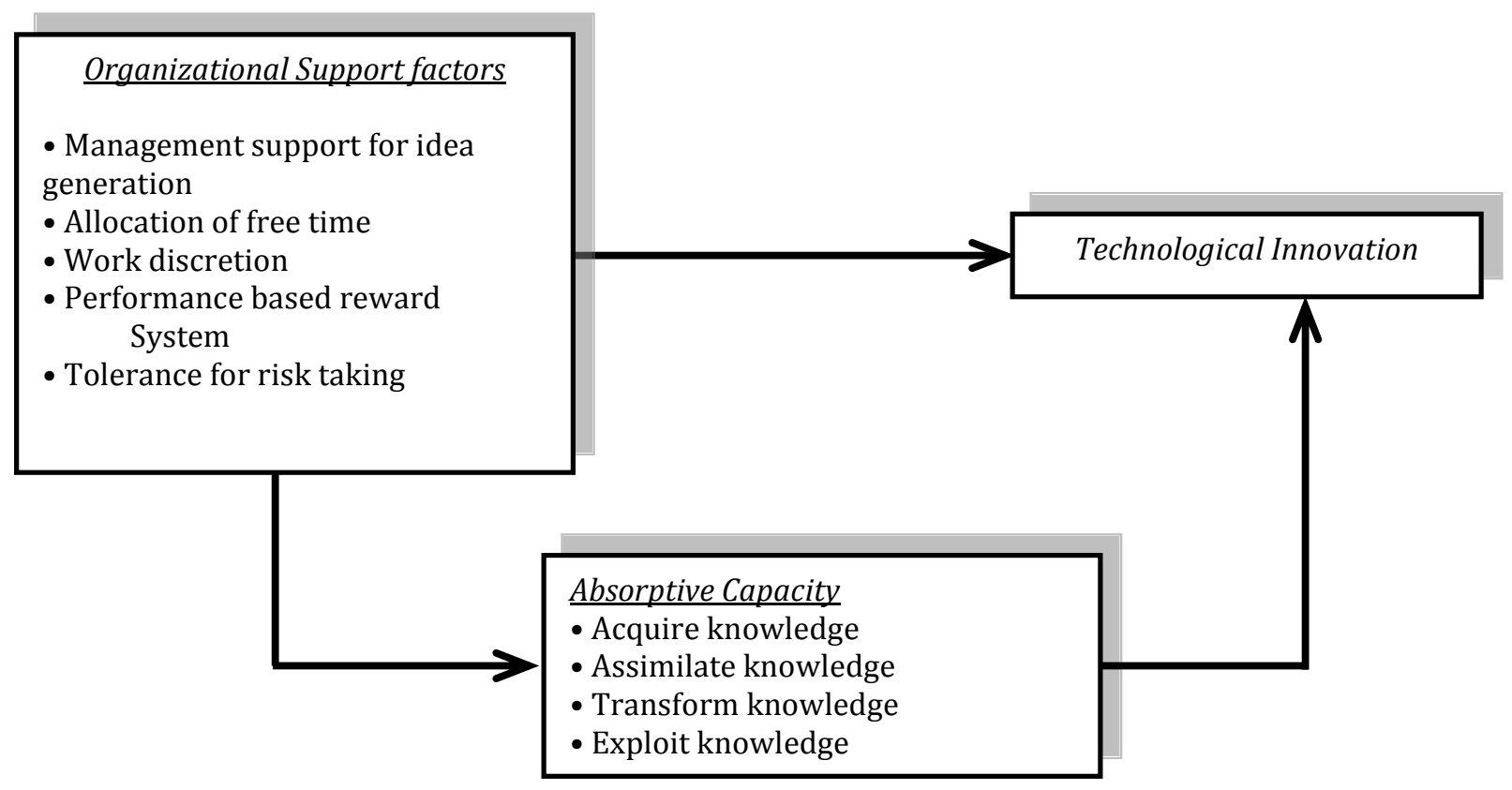

Figure1. Research Framework 


\section{Methodology}

Research Design: Researchers have used cross-sectional design for this research because this design gives the possibility to collect data about a particular phenomenon at a particular time (Saunders et al., 2009) in order to achieve the research's primary objective by validate the proposed model. Temporal dimension, on the other hand seems as very significant to this research so as to be able to determine the effect of OSFs on TI and ACAP on one hand and the mediating role of ACAP on the other hand. This type of data can best be justified through a typical cross-sectional design where the data can be collected at one point in time (Sekaran \& Bougie, 2011) hence the use of longitudinal study is not appropriate in this current research.

Sampling: To select the industry; this research was interested in two criteria: first, the industry to which the technological innovation were important. Second the industry that had developed appropriate external relationships in order to developing its absorptive capacity. Electricity sector in Kurdistan region in northern of Iraq - Sulaimani city was competent in terms of both of the criteria and selected as research's target industry. After arrangements with Directorate of Electricity, three out of the eleven branches selected to deliver the questionnaires personally including the headquarter of the directorate, the directorate of production electric power and the directorate of electric power transmission, however, the reasons behind selecting these branches are embodied in their ability to access to other directorates information, all training courses held in coordination with these branches especially the headquarter and the high experience of their engineers given to their service period which was more than 5 years. Questionnaires were distributed to 100 middle and first-level engineers of these branches. Of the total of 100 questionnaires distributed, 52 were usable which gave a response rate of 52 per cent.

Administration: The organization in our sample was questioned by personally distributed between December 2011 and January 2012. In this research, items used to measure the variables were adapted from previous studies; all variables were measured using multiple items. All items were measured using a fivepoint Likert-type scale (ranging from $1=$ strongly disagree to $5=$ strongly agree). Below, a brief description of measurement approaches for each variable in the model. Organizational support factors were measured using eighteen items adapted from Alpkan et al. (2010) which focused on: Management support for idea generation, Allocation of free time, Work discretion, Performance based reward System and Tolerance for risk taking. A fourteen-item scale measuring Absorptive Capacity was developed by Flatten et al. (2011). It measures simultaneously both of Potential Absorptive Capacity and Realized Absorptive Capacity dimensions through seven items for each dimension. Where Technological Innovation in both dimensions product innovation and process innovation was measured through six items adapted from Murat and Baki study in (2011). Appendix 1 depicts the items for the variables and statistical tests for validity. While Cronbach's Alpha scores of all the factors are all above 0.60 , it was 0.72 for OSFs, 0.71 for ACAP and 0.70 for TI. This indicates that internal consistency levels of our variables are sufficiently reliable (Nunnally, 1970). In this research data analysis was performed by multiple regressions. In order to get data analysis done, SPSS 19.0 for Windows software packages were used in this research.

\section{Results}

The descriptive statistics and correlation matrix of research variables are illustrated in Table1. The correlation coefficients between the independent variable Organizational Support Factors (OSFs), the Mediation variable Absorptive capacity (ACAP), and the dependent variable Technological Innovation (TI). Table 1 shows that OSFs positively and significantly correlated with TI $(r=0.435, \mathrm{p}<0.01)$ and positively and significantly correlated with ACAP $(r=0.558, \mathrm{p}<0.01)$. Besides, ACAP positively and significantly correlated with TI $(r=0.551, \mathrm{p}<0.01)$. These results demonstrate that OSFs and ACAP have been important predictors of TI in the public sector in Iraq. A series of regression analysis were further performed to examine the strength of relationships among these variables. In particular the mediation role of ACAP in explaining the relationship between OSFs and TI among engineers in the public sector organizations was tested. Table 2 provides regression analyses results for the relationship between OSFs and TI, as mediated by ACAP. OSFs have a positive and significant influence on TI $(\beta=0.435, \mathrm{p}<0.001)$ thus supporting $H 1$. As for the links to the literature, our findings are in some extent parallel with similar findings of different research in the recent time. For instance, Alpkan et al. (2010) find positive relations between OSFs and innovations; Hornsby et al. 
(2009) find causal links between top management support and the number of innovative ideas implemented. OSFs were also found positively related to ACAP $(\beta=0.558, \mathrm{p}<0.001)$ hence confirming $H 2$. These results are consistent with the findings of Laukkanen (2012) study who find that OSFs included in her study represent an internal antecedent building block for ACAP. On the other hand, ACAP has strong and significant relation with TI $(\beta=0.551, p<0.001)$, thus providing support for $H 3$. These results support the conceptual assumptions of Laforet, (2011) and parallel with the findings of Caccia-Bava et al. (2006) study which indicate that ACAP can help in fostering TI facilely. As evidenced by the significant interaction, ACAP served as a mediating factor in the relationship between OSFs and TI $(\beta=0.448, p<0.01)$ thus supporting $H 4$. This confirms the result of Saenz et al., (2011) study that pointed out the mediation role of ACAP in fostering innovation. Further, OSFs had a significant main effect on TI and could explain $17 \%$ of the variance in TI for public sector organizations in this research sample. As exhibited in Table 2, when both OSFs and ACAP were included, both exhibited significant main effects on TI and could explain $30 \%$ of the variance in TI.

Table 1: Descriptive statistics and correlations

\begin{tabular}{llllll}
\hline Variables & Mean & SD & OSFs & ACAP & TI \\
\hline OSFs & 3.89 & 0.36 & 1 & & \\
ACAP & 3.90 & 0.35 & $0.558^{* *}$ & 1 & \\
TI & 3.98 & 0.38 & $0.435^{* *}$ & $0.551^{* *}$ & 1 \\
Notes: Significant at: ${ }^{* *} p<0.01 ;$ & $n=52$ & & & \\
\hline
\end{tabular}

Table 2: Results of regression analysis

\begin{tabular}{|c|c|c|c|c|c|c|c|}
\hline Variables & Step $1(\beta)$ & Step $2(\beta)$ & Step $3(\beta)$ & $\begin{array}{l}\text { Step } 4 \\
(\beta)\end{array}$ & $t$-value & \multicolumn{2}{|c|}{$\begin{array}{l}\text { Collinearity } \\
\text { statistics }\end{array}$} \\
\hline Step 1 & & & & & & Tolerance & VIF \\
\hline $\begin{array}{l}\text { OSFs } \\
\text { TI }\end{array}$ & $0.435^{* * *}$ & & & & 3.412 & 1.000 & 1.000 \\
\hline \multicolumn{8}{|l|}{ Step 2} \\
\hline $\begin{array}{l}\text { OSFs } \\
\text { ACAP }\end{array}$ & & $0.558^{* * *}$ & & & 4.750 & 1.000 & 1.000 \\
\hline \multicolumn{8}{|l|}{ Step 3} \\
\hline $\begin{array}{l}\text { ACAP } \\
\text { TI }\end{array}$ & & & $0.551^{* * *}$ & & 4.668 & 1.000 & 1.000 \\
\hline \multicolumn{8}{|l|}{ Step 4} \\
\hline OSFs & & & & 0.185 & 1.309 & 0.689 & 1.451 \\
\hline ACAP & & & & $0.448^{* *}$ & 3.137 & 0.689 & 1.451 \\
\hline \multicolumn{8}{|l|}{ TI } \\
\hline$F$ & $11.639 * * *$ & $22.560^{* * *}$ & $21.791^{* * *}$ & $11.908^{* * *}$ & & & \\
\hline$R^{2}$ & 0.189 & 0.311 & 0.304 & 0.327 & & & \\
\hline Adj. $R^{2}$ & 0.173 & 0.297 & 0.290 & 0.300 & & & \\
\hline
\end{tabular}

Findings Interpretation: This research revealed that TI can be effectively practiced with the aid of ACAP. This may be because the intents of the OSFs and the objectives of the ACAP and TI complement each other. Based on the research questions more discussions will be provided below. Several of theoretical frameworks and empirical researches (Wiengarten et al., 2013; AbuMansor et al., 2012; Garrido-Moreno et al., 2011) have examined the effects of OSFs as a set to understand its integrated role, because they do not exist separately within the organization, even if they found in varying degrees in different organizations. Within this context, this research tries to test the integrated role of OSFs on TI. Thus, the first research question was: What is the relationship between OSFs and TI? This research shows that OSFs highly impacted on the TI in public organization in Iraq and that may be attributed to the nature of such factors which represent the infrastructure of TI. Current research finding empirically supports to theoretical debates that OSFs can play 
an important role to leverage TI. Thus, this research speculates that TI will be more prosperous by addressing and enhancing the supportive environment especially in terms of managerial support factors included in this research. This result is also consistent with prior research (Wang \& Han, 2011; Nagati \& Rebolledo, 2012) providing additional evidence that OSFs is strong essential motivator for TI. These findings were expected based on the existing literature, this research tried to add value by empirically examine the effect of OSFs on TI.

The second research question was: What is the relationship between OSFs and ACAP? The research shows that the availability of OSFs is crucial for fostering ACAP due to two main reasons. The first and the most important reason is that the ACAP is not a spontaneous process particularly with regard to the knowledge sharing activities among members in order to assimilate the external knowledge, and here the role of OSFs manifested in motivating people to share their knowledge, for instance, by providing rewards and support new idea generation. The second reason that OSFs may affect ACAP is based on the perspective of scholars (Miczka \& Gröbler, 2010; Fletcher \& Prashantham, 2011; Liu \& Hsu, 2011). This perspective indicates that ACAP represents the cornerstone of competitive advantage for the organization; therefore there is a need for the presence of factors that grant activate ACAP in the present and allow for enhancing it in future. In line with prior researches (Minguela-Rata et al., 2012 ; Wang \& Han, 2011; Liao et al., 2010 ;Sparrow et al., 2009) this research tries to deal with organization's ACAP as a set to evaluate its role in a comprehensive manner, to understand its total effects on TI. Thus, the third question of this research was: What is the relationship between ACAP and TI? Not surprisingly, there is a significant relationship between ACAP and achieved TI. It is believed that this occurs due to the objectives of ACAP activities which centered on the creation of new knowledge underpinning the innovation and this new knowledge what employees need to raise their practical experience. This result concerted with the attitudes of previous literatures (Wang \& Han, 2011; Laforet, 2011; Gebauer et al., 2012) which highlighted that ACAP has a determined role in the frequency and volume of innovation and that may give clues to the possibility of innovation in the future. Fourth question was: Does the ACAP positively mediate the relationship between OSFs and TI? This research investigated the mediating role of ACAP on the relation between OSFs and TI. It can be observed how the significant impact of OSFs disappeared from the model where ACAP has achieved a full mediation impact on the relation between OSFs and TI. It is clear that the development and TI of such sensitive industry in a country depend on two things, first the extent to which the organization can provide the suitable supportive factors, second, the abilities of individuals to mobilize knowledge absorption.

\section{Implication}

The major contribution to the literature in this research is to draw attention to the importance of OSFs and the mediating role of ACAP on TI. Although there is a vast body of research on TI, still there is scant evidence about the effects of these two concepts on TI. This research has attempted to highlight this gap and bridged it empirically. This research has significant practical implications for Iraqi organizations especially in the public sector. Managers must recognize the importance of their role in enhancing technological innovation which represents a very substantial resource for learning new techniques, solving problems, and creating innovative abilities in Iraqi organization. Meanwhile, in order to turn knowledge into actions and have better innovation, organizations may need to understand the main characteristics of their knowledge and figure out the relationship with organization's ACAP. Moreover, all people should feel and know that if they behave with the appropriate amount of freedom to take risky ideas for innovation, they will be supported in their works, their proposed ideas will be listened to, they will be encouraged for achieving their ideas with necessary emotional and physical assistance, and even if their ideas fail they will not be punished. Iraqi governments set on formulating policies to foster organizations' ACAP would be well advised to support organizations in public sector, in conjunction with initiatives aimed at increasing cooperation with foreign companies to increase their managerial experiences and support their ACAP to exploit externally generated knowledge.

Limitation: The research has some limitations that should be highlighted. As is clear this research focused its attention on internal factors only by examining a somewhat small sample in power industry. Therefore, it is advised that future research should consider using both internal and external factors that may affect TI, using relatively another sector in large and representative sample to evaluate the effect of OSFs on TI across 
varying public sectors. In addition, later studies models may be enlarged with some control variables, like firm size and age, and other comparable organizational drivers of innovation, e.g. social and human capital.

Summary: Results from this research suggest five OSFs antecedents strongly influence the perceived TI in the Iraqi public sector organizations. Not surprisingly, Management support for idea generation, Allocation of free time, Work discretion, Performance based reward System, and the Tolerance for risk taking were significant essential motivators to ACAP by the selected respondents. On the other hand, ACAP has a significant impact to boost the organizational capability for innovation and activate the prior knowledge by combining it with the new assimilated from external resources. It is also proved that the relationship between OSFs and TI is influenced by mediated role of ACAP. Notably, the new TI depends heavily on employees' ability to absorb the external generated knowledge this ability which is not a natural behavior of many individuals but need to be fostered and refined by OSFs as a fundamental input element for such value adding process. Greater new technological innovation has its implications on public sector organizations' performance and responds to changing environments to be more resilient and arrive at the desired results.

\section{References}

AbuMansor, N. N., Chakraborty, A. R., Yin, T. K. \& Mahitapoglu, Z. (2012). Organizational Factors Influencing Performance Management System in Higher Educational Institution of South East Asia. ProcediaSocial and Behavioral Sciences, 40(1), 584- 590.

Akgun, A. E., Keskin, H. \& Byrne, J. (2010) .Procedural justice climate in new product development teams: antecedents and consequences. Journal of Product Innovation Management, 27 (7), 1096-1111.

Akguna, A. E., Byrneb, J. C., Lynnc, J. S. \& Keskin, H. (2007). Team stressors, management support, and project and process outcomes in new product development projects. Technovation, 27(10), 628-639.

Alpkan, L., Bulut, C., Gunday, G., Ulusoy, G. \& Kilic, K. (2010). Organizational support for intrapreneurship and its interaction with human capital to enhance innovative performance. Management Decision, 48(5), $732-755$.

Amiryany, N., Huysman, M., Man, A. \& Cloodt, M. (2012). Acquisition reconfiguration capability. European Journal of Innovation Management, 15(2), 177 - 191.

Andersén, J. (2012). Protective capacity and absorptive capacity: Managing the balance between retention and creation of knowledge-based resources. The Learning Organization, 19(5), $440-452$.

Andersén, J. \& Kask, J. (2012). Asymmetrically realized absorptive capacity and relationship durability. Management Decision, 50(1), 43 - 57.

Arpaci, I. (2010). E-government and technological innovation in Turkey: Case studies on governmental organizations. Transforming Government: People, Process and Policy, 4(1), 37 - 53.

Bhardwaj, B. R. \& Sushil, L. (2012). Internal environment for corporate entrepreneurship: Assessing CEAI model for emerging economies. Journal of Chinese Entrepreneurship, 4(1), 70 - 87.

Bierly, P. E., Damanpour, F. \& Santoro, M. D. (2009). The Application of External Knowledge: Organizational Conditions for Exploration and Exploitation. Journal of Management Studies, 46(3), 481-509.

Bowen, S. (2012). April 2012 Quarterly Report to Congress (p. 158). Arlington. Retrieved from http://www.sigir.mil/

Caccia-Bava, M. D., Guimaraes, T. \& Harrington, S. J. (2006). Hospital organization culture, capacity to innovate and success in technology adoption. Journal of Health Organization and Management, 20(3), 194 217.

Chianga, F. T. \& Birtchb, T. A. (2008). Achieving task and extra-task-related behaviors: A case of gender and position differences in the perceived role of rewards in the hotel industry. International Journal of Hospitality Management, 27(4), 491-503.

Chung, C. (2012). National, sectoral and technological innovation systems: The case of Taiwanese pharmaceutical biotechnology and agricultural biotechnology innovation systems (1945-2000). Science and Public Policy, 39(1), 271-281. doi:10.1093/scipol/scs008

Darini, M., Pazhouhesh, H. \& Moshiri, F. (2011). Relationship between Employee's Innovation (Creativity) and time management. Procedia - Social and Behavioral Sciences, 25(1), 201-213.

Dasgupta, M., Gupta, R. K. \& Sahay, A. (2011). Linking Technological Innovation, Technology Strategy and Organizational Factors: A Review. Global Business Review, 12(2), 257-277. 
Deng, P. (2010). Absorptive capacity and a failed cross-border M\&A. Management Research Review, 33(7), 673 $-682$.

Dixon, S. E. \& Day, M. (2007). Leadership, administrative heritage and absorptive capacity. Leadership \& Organization Development Journal, 28(8), 727 - 748.

Druker, P. (2002). The Discipline of Innovation. Harvard Business Review, 80(8), 95-103.

Faff, R., Hallahan, T. \& McKenzie, M. (2011). Women and risk tolerance in an aging world. International Journal of Accounting and Information Management, 19(2), 100 - 117.

Feghali, T. \& El-Den, J. (2008). Knowledge transformation among virtually-cooperating group members. Journal of Knowledge Management, 12(1), 92 - 105.

Flatten, T. C., Greve, G. I. \& Brettel, M. (2011). Absorptive Capacity and Firm Performance in SMEs: The Mediating Influence of Strategic Alliances. European Management Review, 8(3), 137-152.

Fletcher, M. \& Prashantham, S. (2011). Knowledge assimilation processes of rapidly internationalizing firms longitudinal case studies of Scottish SMEs. Journal of Small Business and Enterprise Development, $18(3), 475-501$.

Garrido-Moreno, A. \& Padilla-Meléndez, A. (2011). Analyzing the impact of knowledge management on CRM success: The mediating effects of organizational factors. International Journal of Information Management, 31(5), 437- 444.

Gebauer, H., Worch, H. \& Truffer, B. (2012). Absorptive capacity, learning processes and combinative capabilities as determinants of strategic innovation. European Management Journal, 30(1), 57- 73.

Güngör, P. (2011). The Relationship between Reward Management System and Employee Performance with the Mediating Role of Motivation: A Quantitative Study on Global Banks. Procedia- Social and Behavioral Sciences, 24(1), 1510-1520.

Gurkov, I. (2005). Innovations in Russian industries: conditions for implementation and impact on competitiveness. Journal for East European Management Studies, 10(3), 387-396.

Hall, R. \& Andriani, P. (2003). Managing knowledge associated with innovation. Journal of Business Research, 56(2), 145-152. doi:10.1016/S0148-2963(01)00287-9.

Han, Z. \& Erming, X. (2012). Knowledge assimilation and exploitation Comparison in corporations with different ownership identity. Nankai Business Review International, 3(1), 31-51.

Hornsby, J. S., Kuratko, D. F., Shepherd, D. A. \& Bott, J. P. (2009). Managers' corporate entrepreneurial actions: examining perception and position. Journal of Business Venturing, 24(3), 236-47.

Howell, J. M. \& Boies, K. (2004). Champions of technological innovation: The influence of contextual knowledge, role orientation, idea generation, and idea promotion on champion emergence. The Leadership Quarterly, 15(1), 123-143.

Indreicaa, E., Cazanb, A. \& Truţac, C. (2011). Effects of learning styles and time management on academic achievement. Procedia-Social and Behavioral Sciences, 30(1), 1096 - 1102.

Jansen, J. J. P., Van Den Bosch, F. A. J. \& Volberda, H. W. (2005). Managing Potential and Realized Absorptive Capacity: How Do Organizational Antecedents Matter? Academy of Management Journal, 48(6), 9991015. doi:10.5465/AMJ.2005.19573106

Jin, Z. \& Navare, J. (2011). Exploring the relationship between risk management and adoptive innovation: A case study approach. World Journal of Entrepreneurship, Management and Sustainable Development, $6(1), 29-37$.

Jing, R., Wan, Y. \& Gao, X. (2010). Managerial discretion and executives' compensation. Journal of Chinese Human Resource Management, 1(1), 17- 30.

Jung-Erceg, P., Pandza, K., Armbruster, H. \& Dreher, C. (2007). Absorptive capacity in European manufacturing: a Delphi study. Industrial Management \& Data Systems, 107(1), 37 - 51.

Kamal, E. M. \& Flanagan, R. (2012). Understanding absorptive capacity in Malaysian small and medium sized (SME) construction companies. Journal of Engineering, Design and Technology, 10(2), 180 - 198.

Kamasak, R. \& Bulutlar, F. (2010). The influence of knowledge sharing on innovation. European Business Review, 22(3), $306-317$.

Kuratko, D. F., Montagno, R. V. \& Hornsby, J. S. (1990). Developing an entrepreneurial assessment instrument for an effective corporate entrepreneurship. Strategic Management Journal, 11(5), 49-58.

Laforet, S. (2011). A framework of organizational innovation and outcomes in SMEs. International Journal of Entrepreneurial Behaviour \& Research, 17(4), 380- 408.

Laukkanen, P. H. (2012). Constituents and outcomes of absorptive capacity - appropriability regime changing the game. Management Decision, 50(7), 1178-1199. 
Liao, K., Tu, Q. \& Marsillac, E. (2010). The role of modularity and integration in enhancing manufacturing performance: An absorptive capacity perspective. Journal of Manufacturing Technology Management, 21(7), $818-838$.

Lin, C., Wub, Y., ChiaChiChang, Wangb, W. \& Cheng-YuLee, L. (2012). The alliance innovation performance of R\&D alliances - the absorptive capacity perspective. Technovation, 32(5), 282-292.

Liu, H. \& Hsu, C. (2011). Antecedents and consequences of corporate diversification: A dynamic capabilities perspective. Management Decision, 49(9), 1510 - 1534.

Liu, X. (2010). Can an international acquisition be an effective way to boost innovation in developing countries? Evidences from China's TFT-LCD industry. Journal of Science and Technology Policy in China, 1(2), $116-134$.

Martinkenaite, I. (2012). Antecedents of knowledge transfer in acquisitions. Baltic Journal of Management, $7(2), 167-184$.

Martín-de Castro, G., Delgado-Verde, M., Navas-López, J. E. \& Cruz-González, J. (2013). The moderating role of innovation culture in the relationship between knowledge assets and product innovation. Technological Forecasting and Social Change, 80(2), 351-363. doi:10.1016/j.techfore.2012.08.012.

Martins, J. D. (2012). Analytical dimensions of knowledge transfer to the subsidiaries. European Business Review, 24(5), 465 - 477.

Michailova, S. \& Jormanainen, I. (2011). Knowledge transfer between Russian and Western firms: Whose absorptive capacity is in question? Critical perspectives on international business, 7(3), $250-270$.

Miczka, S. \& Gröbler, A. (2010). Merger dynamics: Using system dynamics for the conceptual integration of a fragmented knowledge base. Kybernetes, 39(9), 1491 - 1512.

Minguela-Rata, B., Benavides, M. C. \& López-Sánchez, J. I. (2012). Knowledge complexity, absorptive capacity and weak ties: An empirical analysis of its effects on franchise systems uniformity. Journal of Manufacturing Technology Management, 23(5), 578 - 592.

Moreno, A. G. \& Meléndez, A. P. (2011). Analyzing the impact of knowledge management on CRM success: The mediating effects of organizational factors. International Journal of Information Management, 31(5), 437- 444 .

Murat, I. M. \& Baki, B. (2011). Antecedents and performance impacts of product versus process innovation: Empirical evidence from SMEs located in Turkish science and technology parks. European Journal of Innovation Management, 14(2), 172 - 206.

Nagati, H. \& Rebolledo, C. (2012). The role of relative absorptive capacity in improving suppliers' operational performance. International Journal of Operations \& Production Management, 32(5), 611 - 630.

Nunnally, J. C. (1970). Introduction to psychological measurement. New York: McGraw-Hill.

Ooi, K., Lin, B., Teh, P. \& Chong, A. Y. (2012). Does TQM Support Innovation Performance in Malaysia's Manufacturing Industry? Journal of Business Economics and Management, 13(2), 366-393.

Ramadani, V. \& Gerguri, S. (2011). Innovations: Principles and Strategies. Advances In Management, 4(7), 712.

Ren, L., Zeng, D. \& Krabbendam, K. (2010). Technological innovation progress in Central China: a survey to 42 firms. Journal of Knowledge-based Innovation in China, 2(2), 152 - 170.

Saenz, M. J., Revilla, E. \& Knoppen, D. (2011, August). Enhancing innovation and efficiency in a supply chain through organizational compatibility: The mediating role of absorptive capacity. Paper presented at the Academy of Management Annual Meeting Proceedings, U.S.A , 1-6.

Saidi, A. N., Mohamed, M. I. \& Idris, A. C. (2012). Organizational Factors in Learning and Development Initiatives. Procedia- Social and Behavioral Sciences, 40(1), 565 - 570.

Saunders, M., Lewis, P. \& Thornhill, A. (2009). Research methods for business students ( $5^{\text {th }}$ ed). London: Person Education Limited.

Sekaran, U. \& Bougie, R. (2011). Research methods for Business: A Skill Building Approach (5th ed). United Kingdom: A John Wiley and Sons.

Sparrow, J., Tarkowski, K., Lancaster, N. \& Mooney, M. (2009). Evolving knowledge integration and absorptive capacity perspectives upon university-industry interaction within a university. Education and Training, 51(8), 648 - 664.

Summers, J. K., Munyon, T. P., Perryman, A. A. \& Ferris, G. R. (2010). Dysfunctional executive behavior: What can organizations do? Business Horizons, 53(6), 581-590. doi:10.1016/j.bushor.2010.06.005 
Tarafdara, M. \& Vaidyab, S. D. (2006). Challenges in the adoption of E-Commerce technologies in India: The role of organizational factors. International Journal of Information Management, 26(6), 428-441. doi:10.1016/j.ijinfomgt.2006.08.001

Tsai, L. (2001). Knowledge Transfer in Intraorganizational Networks: Effects of Network Position and Absorptive Capacity on Business Unit Innovation and Performance. Academy of Management Journal, 44(5), 996-1004.

Tseng, C. Y., Pai, D. C. \& Hung, C. H. (2011). Knowledge absorptive capacity and innovation performance in KIBS. Journal of Knowledge Management, 15(6), 971 - 983.

Wang, C. \& Han, Y. (2011). Linking properties of knowledge with innovation performance: the moderate role of absorptive capacity. Journal of Knowledge Management, 15(5), 802 - 819.

Wei, Y. S. \& Gima, K. A. (2009). The moderating role of reward systems in the relationship between market orientation and new product performance in China. Intern journal of Research in Marketing, 26(2), 89-96.

Weigelt, C. \& Sarkar, M. B. (2012). Performance Implication of Outsourcing for Technological Innovation: Managing the Efficiency and Adaptability trade-Off. Strategic Management Journal, 216, 189-216. doi:10.1002/smj

Wiengarten, F., Humphreys, P., Cao, G. \& McHugh, M. (2013). Exploring the Important Role of Organizational Factors in IT Business Value: Taking a Contingency Perspective on the Resource-Based View. International Journal of Management Reviews, 15(1), 30-46.

Wu, S. \& Fang, W. (2010). The effect of consumer-to-consumer interactions on idea generation in virtual brand community relationships. Technovation, 30(11/12), 570-581.

Yolles, M., Fink, G. \& Dauber, D. (2011). Organizations as emergent normative personalities: part 1, the concepts. Kybernetes, 40(5/6),635-669.

Zahra, S. A. \& George, G., (2002). Absorptive Capacity: A review, Reconceptualization, and Extension. Academy of Management Review, 27(2), 185-203.

Zahra, S. A. \& Hayton, J. C. (2008). The effect of international venturing on firm performance: The moderating influence of absorptive capacity. Journal of Business Venturing, 23(2), 195-220.

Zair, E. (2012). Training employees of the electricity on the operation and maintenance of wireless transmission equipment. Newsabah. Retrieved from http://www.newsabah.com/ar/2359/21/79772/ (on 20, August, 2012). 
Appendix1: Items for the variables and Factor analysis

\begin{tabular}{|c|c|c|c|c|c|}
\hline Factor1:Organizational support factors & 1 & 2 & 3 & 4 & 5 \\
\hline \multicolumn{6}{|l|}{ Management support for idea generation } \\
\hline 1-The development of new and innovative ideas are encouraged & 0.879 & & & & \\
\hline $\begin{array}{l}\text { 2-Senior managers encourage innovators to bend rules and rigid } \\
\text { procedures in order to keep promising ideas on track }\end{array}$ & 0.877 & & & & \\
\hline $\begin{array}{l}\text { 3-Developing one's own ideas is encouraged for the improvement } \\
\text { of the firm }\end{array}$ & 0.934 & & & & \\
\hline \multicolumn{6}{|l|}{ Allocation of free time } \\
\hline $\begin{array}{l}\text { 1-Our employees always seem to have plenty of time to get } \\
\text { everything done }\end{array}$ & & 0.788 & & & \\
\hline $\begin{array}{l}\text { 2-Our employees have enough time to spend for developing new } \\
\text { ideas }\end{array}$ & & 0.940 & & & \\
\hline $\begin{array}{l}\text { 3- Our employees' workloads do not prevent them to conduct } \\
\text { innovative projects }\end{array}$ & & 0.886 & & & \\
\hline \multicolumn{6}{|l|}{ Work discretion } \\
\hline $\begin{array}{l}\text { 1-Our employees have the freedom to implement different work } \\
\text { methods for doing major and routine tasks from day to day }\end{array}$ & & & 0.952 & & \\
\hline $\begin{array}{l}\text { 2-It is basically the employees' own responsibility to decide how } \\
\text { their jobs get done }\end{array}$ & & & 0.919 & & \\
\hline $\begin{array}{l}\text { 3- This organization provides the employees with the freedom to } \\
\text { use their own judgment and methods }\end{array}$ & & & 0.957 & & \\
\hline \multicolumn{6}{|l|}{ Performance-based reward system } \\
\hline $\begin{array}{l}\text { 1-The rewards that employees received or will receive are } \\
\text { dependent on their work on the job }\end{array}$ & & & & 0.785 & \\
\hline $\begin{array}{l}\text { 2-Employees with innovative and successful projects will be highly } \\
\text { rewarded }\end{array}$ & & & & 0.718 & \\
\hline $\begin{array}{l}\text { 3-Employees will be appreciated by their managers' if they perform } \\
\text { very well }\end{array}$ & & & & 0.639 & \\
\hline 4-Employees from every level will be rewarded, if they innovate & & & & 0.832 & \\
\hline $\begin{array}{l}\text { 5-Managers increase employee's job responsibilities if they } \\
\text { perform well }\end{array}$ & & & & 0.748 & \\
\hline \multicolumn{6}{|l|}{ Tolerance for risk taking } \\
\hline $\begin{array}{l}\text { 1-There are several options within the organization for individuals } \\
\text { to get financial support to actualize their innovative projects }\end{array}$ & & & & & 0.974 \\
\hline 2-Money is often available to get new project ideas off the ground & & & & & 0.906 \\
\hline $\begin{array}{l}\text { 3-The term risk taker is considered a positive attribute for people } \\
\text { in our firm }\end{array}$ & & & & & 0.887 \\
\hline $\begin{array}{l}\text { 4-Individual risk takers are often recognized for their willingness } \\
\text { to champion new projects, whether eventually successful or not }\end{array}$ & & & & & 0.866 \\
\hline
\end{tabular}




\begin{tabular}{|c|c|c|c|c|}
\hline Factor2: Absorptive Capacity & 1 & 2 & 3 & 4 \\
\hline \multicolumn{5}{|l|}{ Acquisition } \\
\hline $\begin{array}{l}\text { 1-The search for relevant information concerning our industry is } \\
\text { every-day business in our firm. }\end{array}$ & 0.739 & & & \\
\hline $\begin{array}{l}\text { 2-Our management motivates the employees to use information } \\
\text { sources within our industry. }\end{array}$ & 0.986 & & & \\
\hline $\begin{array}{l}\text { 3-Our management expects that the employees deal with } \\
\text { information beyond our industry. } \\
\text { Assimilation }\end{array}$ & 0.736 & & & \\
\hline $\begin{array}{l}\text { 1-In our firm ideas and concepts are communicated cross- } \\
\text { departmental. }\end{array}$ & & 0.751 & & \\
\hline $\begin{array}{l}\text { 2-Our management emphasizes cross-departmental support to solve } \\
\text { problems. }\end{array}$ & & 0.961 & & \\
\hline $\begin{array}{l}\text { 3-In our firm there is a quick information flow, e.g., if a business unit } \\
\text { obtains important information it communicates this information } \\
\text { promptly to all other business units or departments }\end{array}$ & & 0.965 & & \\
\hline $\begin{array}{l}\text { 4-Our management demands periodical cross-departmental } \\
\text { meetings to interchange new developments, problems, and } \\
\text { achievements. } \\
\text { Transformation }\end{array}$ & & 0.751 & & \\
\hline $\begin{array}{l}\text { 1-Our employees have the ability to structure and to use collected } \\
\text { knowledge. }\end{array}$ & & \multicolumn{3}{|c|}{0.814} \\
\hline $\begin{array}{l}\text { 2-Our employees are used to absorb new knowledge as well as to } \\
\text { prepare it for further purposes and to make it available. }\end{array}$ & & \multicolumn{3}{|c|}{0.919} \\
\hline $\begin{array}{l}\text { 3-Our employees successfully link existing knowledge with new } \\
\text { insights. }\end{array}$ & & \multicolumn{3}{|c|}{0.791} \\
\hline $\begin{array}{l}\text { 4-Our employees are able to apply new knowledge in their practical } \\
\text { work. }\end{array}$ & & \multicolumn{3}{|c|}{0.934} \\
\hline Exploitation & & & & \\
\hline 1-Our management supports the development of prototypes. & & & & 0.833 \\
\hline $\begin{array}{l}\text { 2-Our firm regularly reconsiders technologies and adapts them } \\
\text { accordant to new knowledge. }\end{array}$ & & & & 0.783 \\
\hline $\begin{array}{l}\text { 3-Our firm has the ability to work more effective by adopting new } \\
\text { technologies. }\end{array}$ & & & & 0.879 \\
\hline Factor3:Technological Innovation & & 1 & & 2 \\
\hline \multicolumn{5}{|l|}{ Product innovation } \\
\hline \multicolumn{2}{|l|}{$\begin{array}{l}\text { 1-The rate of product innovation into the firm among innovation activities is } \\
\text { the highest over last three years }\end{array}$} & \multicolumn{3}{|l|}{0.890} \\
\hline \multicolumn{2}{|l|}{ 2-We describe ourselves as a firm focusing on product/service innovation } & \multicolumn{3}{|l|}{0.669} \\
\hline \multicolumn{5}{|l|}{ Process innovation } \\
\hline $\begin{array}{l}\text { 1-The rate of process innovation into the firm among innovation activit } \\
\text { the highest over the last three years }\end{array}$ & ties is & & & 0.791 \\
\hline 2-We describe ourselves as a firm focusing on process innovation & & & & 0.888 \\
\hline 3-Our new processes are often perceived as very novel by customers & & & & 0.822 \\
\hline
\end{tabular}

